\title{
Analysis of Factors that Lead to Financial Distress for Property and Real Estate Companies in Indonesia
}

\author{
Theresia Trisanti* \\ STIE YKPN
}

Email: theresiatrisanti@gmail.com

\begin{abstract}
This study is to examine and analyze the effect of the independent variables, namely profitability, liquidity, company size, leverage, and sales growth on the dependent variable in the form of financial distress. The population in this study was property and real estate companies listed on the Indonesia Stock Exchange for the period 2016 - 2019. By using purposive sampling technique. data analytical technique used is descriptive statistic, classic assumption test and hypothesis testing in the form of SmartPLS analysis. The test results show that the profitability, liquidity, and leverage variables affect the financial distress but growth didn't affect. Company size can mediate the relation for variable profitability, leverage liquidity to financial distress.
\end{abstract}

Keywords: profitability, liquidity, company size, leverage, sales growth and financial distress.

\section{Introduction}

The development of the modern economy that is happening in Indonesia is increasing significantly. This development has led to demands for companies to develop innovation and expand to be able compete. Companies that are unable to compete will experience bankruptcy, before bankruptcy occurs companies will experience financial distress (financial difficulties). A phenomenon of financial distress when many companies experience delisted. According to Platt and Platt (2008) financial distress is the stage of the condition company finances before bankruptcy or liquidation. Platt (1995) reserach revealed that financial distress is the initial stage or condition for the first time a decline in company finances before bankruptcy or liquidation occurs. Companies that have problems if left unchecked will experience bankruptcy, these financial problems are not only affected by the company but also many parties, namely the stakeholders and shareholders of the company. The company will try hard to avoid a financial crisis because if it happens the loss will not only the company but also the stakeholders.

Financial distress will be very useful information for the company because financial distress can be used as an early warning before bankruptcy occurs so that the company will easily anticipate bankruptcy by improving the company's performance. Some researchers concluded by improving company performance is positively expected to provide significant positive impact and prevent the company from conditions of financial distress. The model in determining the prediction of bankruptcy symptoms of a company is needed by various parties such as management, shareholders, investors, creditors, the government, auditors in the decision making process (Almilia \& Kristijadi, 2003; Rohmadini et al., 2018). Bankruptcy itself in Indonesia is regulated in law. No.1 of 1998 concerning bankruptcy, the contents of which mention debtors who have two or more creditors and cannot repay at least 


\section{Theresia Trisanti}

one debt which is due and cannot be billed, are declared bankrupt by an authorized court decision, both at their own request, and at the request of five people or more creditors. This request can also be submitted by the public prosecutor's office. Mistakes in predicting the continuity of a company's operations can result in investor confidence in the company decreasing or investors will not invest their funds in the company. This can result in the company having difficulties in obtaining additional funds from loans to creditors (Garcia, Appendini, 2018).

The company's financial statements are a source of information that reflects financial condition and company performance in a certain period. According to Couwenberg (2015), Fitzpatrick and Ogden (2011) models in predicting financial distress can use analysis financial ratios and non-financial variables such as economic conditions, audit opinions, against financial statements. The existence of threats of these problems makes para managers must think hard about strategies to anticipate the state of gloom finance that might attack the company. For example when the financial crisis happened in Indonesia on 1998 making many companies experience financial difficulties because of many companies have debts to third parties, at which time interest debt is high enough so that their obligations are also high. Phillips and Sertsios (2013) expressed their opinion that there are several factors that can trigger financial distress, namely the existence of a series of mistakes, improper decision making, interconnected weaknesses that have a direct or indirect impact on company management and supervision which is lacking on company finances. Financial distress will usually begin with financial difficulties marked by uncertainty about the company's profitability.

Financial statements will be very useful information to determine the company's financial condition, so information from the financial statements will determine whether a company is experiencing a financial crisis or not. Md.Rus et al., (2013) said that a company that has a bad financial condition by having a negative operating profit, negative net profit, negative equity book value and conducting a merger can be categorized as having a financial crisis or financial distress. Judging from the financial statements according to Husein and Pambekti (2015) there are 3 (three) conditions that can cause financial distress, namely lack of company capital, excessive debt and interest burdens, and losses incurred to the company. These three aspects are interrelated so the company must maintain its balance so that financial distress does not occur which will then have an impact on the company's bankruptcy. Platt et al., (1995) argue that financial distress information (financial crisis) has several benefits:

1. Management will be able to quickly take precautions before bankruptcy occurs.

2. Management can do a merger or takeover in an effort to repay corporate debt and to manage the company better.

3. Financial distress information can be an early warning before a bankruptcy occurs in the company in the future.

Researcher chooses the property, real estate and building construction (PRBC) sectors because this sectors are one of the investment alternatives that investors are interested in. Investments in this sector are long-term investments and PRBC are multipurpose assets that can be used by companies as collateral, therefore the PRBC companies has a high capital structure. However, the PRBC sectors are the most vulnerable sectors in the macro industry against fluctuations in interest rates, inflation and exchange rates which will ultimately affect purchasing power community. Year 2014 and 2019, Indonesia holds legislative and 


\section{Theresia Trisanti}

presidential elections causing political obscurity and economic ambiguity the big one. Ahead of the general election, the Indonesian developers tend to delay new projects, delay projects property is also the impact of declining loan disbursements a higher mortgage and market interest rate. Based on the explanation above, it is possible for companies to experience financial distress.

In an effort to avoid a financial crisis the company must be able to manage and maintain the company's financial stability properly, this can be done by seeking to increase sales so that the difference between revenue and costs will be positive or the company will experience profits (Korteweg, 2011; Kristanti et al., 2016). According to Keasey et al. (2015) profit margin, leverage, liquidity and company growth are the most dominant ratios to determine the company's financial distress. The last intern al factor of the company in this study that can affect financial distress is the size of the company. The size of a company illustrates how big the total assets owned by the company. According to Mselmi et al., (2017) companies with large total assets will easily diversify and the possibility of companies experiencing bankruptcy will be smaller. The same thing was stated by Betz et al., (2014)that if the total assets of a company are increasingly the company will be able to pay off obligations in the future, so that the company can avoid financial problems. This study uses the ratio of profitability, liquidity, sales growth, leverage and company size to detect whether a company is experiencing a financial crisis or not.

Oaten and Cheng, (2007) argues that the ratio of profitability, leverage, liquidity is a significant indicator in determining the company's financial distress. Another study by Shahwan, (2015) concluded that profit margins, leverage, liquidity and company growth are ratios that can also be used to determine a company's financial distress. This study combines the two studies above by using the ratio of profitability, liquidity, leverage and sales growth to detect whether these variables are able to detect whether the company is experiencing a financial crisis or not. Another contribution of this research is to use the company size variable as a mediating variable. Company size can be used to represent the financial characteristics of the company. Company size is a scale that can be calculated by the level of total assets and sales which can indicate the condition of the company where a larger company will have an excess in the source of funds obtained to finance its investment in obtaining a profit. Large companies that are well established will find it easier to obtain capital in the capital market compared to small companies. Because this ease of access means that large companies have greater flexibility. It is assumed that large companies are more resilient in facing financial distress than smaller companies. It is expected that the mediating variable company size can strengthen the relationship between the independent variable to the dependent.

Based on the background described above, the researcher identified the problem as follows:

1. How does profitability affect financial distress in property and real estate companies?

2. What is the effect of liquidity on financial distress in Property and Real Estate companies?

3. How does leverage influence financial distress on Property and Real Estate companies?

4. What is the effect of sales growth on financial distress on Property and Real Estate?

5. How does the size can mediate the relationship of profitability, liquidity, leverage and sales growth to financial distress on the Property and Real Estate companies? 


\section{Theresia Trisanti}

\section{Literature Review}

Signal theory using this research, because signal theory can used to explain that financial statements are used to give positive signals (good news) and negative signals (bad news) to the capital market and public. Elfakhani and Lung (2003) conducted research on the regulation of financial ratio comparisons in giving signals of financial distress by using multimeasuring techniques consisting of emerging markets, score models, comparative ratio analysis, and ratio trend analysis and logistic models as benchmarking measures. This research shows that financial statement information can be used as a media to find out the signal of a company's failure. Based on the explanation of the signal theory, the researcher is of the opinion that the signal theory is related to this research, which has a relationship in determining financial distress companies. Because the information from the company's management is written in the company's financial statements that provide a signal to analyze the company's performance and can show and give a turnaround failure or success. As mentioned by Bhattacharjee and Han (2014) financial statements are a process of analysis and assessment that helps in answering questions as a means to an end. Financial statements are very important for every company, both companies that have gone public or not, because it can be used to determine the performance and financial condition of the company so that it can predict the potential for bankruptcy in the future.

There are some experts who have defined financial distress related to them, namely Platt (1995) revealed that financial distress is the initial stage or condition for the first time a decline in company finances before bankruptcy or liquidation occurs. Financial distress according to Senbet and Wang (2010)is a condition that requires companies to pay obligations or debts due but the company cannot pay these obligations. So it can be concluded that financial distress does not occur when the company has gone bankrupt but will occur before the bankruptcy occurs, therefore financial distress will be very effective if used by the company or stakeholders as a detection of potential bankruptcy in a company. If the company can detect potential bankruptcy, then the management can take actions and reanalyze all activities of the company that are considered to be a factor that causes financial distress or financial crisis before the company experiences a real bankruptcy.

The benefits of financial distress information on several parties concerned to the company according to Gopalan and Xie (2011), namely:

a. Lenders. Benefits for lenders or creditors are in the decision making efforts which companies will be given loans and to monitor loans that have been given,

b. Investors. The benefit for investors on financial distress information is that investors will easily see the signs that the company is bankrupt, so this is used by investors to sell their shares and bonds as quickly as possible.

c. Government. The benefit for the government is that it can detect company bankruptcy more quickly so that the government can take the necessary initial action because the government has responsibility for the running of a business.

d. Accounting. For accountants financial distress information will be useful in assessing the sustainability of a company's business.

Moreover, financial statement analysis is a process to identify weaknesses and financial strengths of the company by explaining the relationship of one account with another account contained in the financial statements. Financial statement analysis is used to identify key changes in financial statements and help users of information in evaluating business 


\section{Theresia Trisanti}

policies that have been implemented and to predict future company performance. The information produced by this analysis will show an early warning sign of a shift towards success or even failure of a company (Elkamhi et al., 2012). In an effort to determine the company's financial distress, financial ratio analysis can be used. Miglani et al., (2015) argues that the ratio of profitability, leverage, liquidity and cash flow coverage are significant indicators in determining a company's financial distress. According to Keasey et al. (2015) profit margin, leverage, liquidity and company growth are the most dominant ratios to determine the company's financial distress. There are several studies that use the Altman ZScore model to reference bankruptcy detection for companies such as research conducted by Lian (2017) and Louwers (1998). This study uses the Altman Z-Score in detecting financial distress, this is because according to Chen et al., (1995) the Altman Z-Score model has a higher level of accuracy in detecting financial distress in a company. In the Altman Z-Score model the classification of company health has been determined which is divided into 3 (three) classifications, namely safe zones or companies that have a low bankruptcy risk, gray areas or middle conditions, and distress zones or potentially strong bankruptcy, with this classification making it easier in determining the condition of a company.

\section{Methodology}

This study uses multiple regression equations as a research model. This is because the researcher tested two or more independent variables on one dependent variable. By using this research model, researcher can determine the level of influence of the independent variables on the dependent variable, and can determine the direction of the relationship between each independent variable related. The Altman Z-Score method is use for financial distress detection, Altman Z-Score expressed in 5 "T" coefficients which represent financial ratios. According to Yudiawati and Indriani (2016) the development of the Altman Z-score model is as follows:

$$
\mathrm{Z}=1.2 \mathrm{X} 1+1.4 \mathrm{X} 2+3.3 \mathrm{X} 3+0.6 \mathrm{X} 4+1.0 \mathrm{X} 5
$$

The explanation above information as follows:

1. $\mathrm{X} 1=$ Working Capital of Total Assets. Working capital is obtained by means of current assets less current liabilities. And total assets are obtained from current assets plus fixed assets.

2. $\mathrm{X} 2=$ Retained Earnings to Total Assets. Retained earnings are a number of profits that are not distributed to shareholders, retained earnings can be seen from the amount of retained earnings listed in the company's financial statements. Total assets are obtained from current assets plus fixed assets.

3. $\mathrm{X} 3=$ Profit before Interest and Tax on Total Assets. Profit before interest and tax or also called earnings before interest and tax (EBIT) is earned from the amount of EBIT stated in the company's financial statements. . Total assets are obtained from current assets plus fixed assets.

4. $\mathrm{X} 4=$ Book Value of Equity to Total Debt Book Value. The book value of equity is obtained from the amount of total company equity while the book value of total debt is seen from the amount of current debt or short-term liabilities with long-term liabilities.

5. $\quad \mathrm{X} 5=$ Sales of Total Sales to Assets Total. Assets are obtained from current assets plus fixed assets. 


\section{Theresia Trisanti}

The criteria used in developing this model are:

1. $\quad Z$ value $>2.99$, the company can be said to be healthy, or has the potential to experience a small bankruptcy

2. Value of $1.81<\mathrm{Z}<2.99$, the company is in the gray area or midway between healthy and distress.

3. $\mathrm{Z}$ value $<1.81$, the company is predicted to go bankrupt or distress

Independent variables are variables that can explain or influence the magnitude of the value of other variables. This variable is also referred to as an influence variable, cause variable or independent variable Platt et al., (1995). In this study the independent variables are as follows:

1. Profitability ratios can show how the company's ability to generate profits. The ratio of profitability and financial distress have the opposite relationship. A high level of profitability ratio will indicate if the company will be less likely to experience financial distress and vice versa. According to Korteweg (2011) the effectiveness and efficiency of companies in using assets will be shown in profitability ratios because profitability ratios measure the ability of companies to generate profits based on the use of company assets. This ratio is usually reflected in ROA or Return on Assets.

\section{Net Income \\ Total Assets}

2. The liquidity ratio describes the company's ability to pay off short-term obligations or current liabilities of the company by utilizing current assets owned by the company (Xu et al., 2015). The division between total current assets and current company debt is a way of calculating liquidity ratios. The company is said to be in a liquid condition meaning that the company is in good health and can meet the company's short-term obligations that have matured, under these conditions it means that the company has total current assets that are greater than current liabilities or short-term liabilities owned by the company (Andre \& Taqwa, 2014).

\section{Current Assets \\ Current Liabilities}

3. Leverage is also one indicator in predicting the occurrence of financial distress in the company. Leverage shows the company's ability to pay or pay off corporate debt, both short-term debt and long-term debt and also leverage is used to see how much debt is used in an effort to finance the company

\section{Total Debts}

Total Assets

4. To detect financial distress, sales growth can also be used as an indicator of its detection. According to Almilia and Kristijadi (2003) sales growth describes the level 


\section{Theresia Trisanti}

of company sales growth in a period. Sales growth is included in the growth ratio. Sales growth will reflect the company's ability to increase sales of the products the company is producing. Sales growth increases when the company is able to run its marketing strategy well so that it has an impact on increasing sales of the company's products. Therefore, when growth sales increase, the company's profits also increase so that it will reflect the company's stable condition and the company will avoid the financial crisis.

$$
\text { Sales Growth } \%=\frac{\text { Sales }_{t}-\text { Sales }_{t-1}}{\text { Sales }_{t-1}}
$$

5. The size of the company becomes a benchmark in determining the size or asset of a company. The size or size of a company can be seen from the total assets or the number of sales made in a period. Large companies will be considered more capable in dealing with the threat of financial distress compared to smaller companies because large companies tend to have large total assets. Based on some previous studies, company size affects corporate stress. Some studies did not get consistency of results. Several studies have explained that if the size of a large company and have a large debt they are reluctant to experience financial distress. In contrast, there are small companies that are able to survive in difficult financial conditions. In other words, smaller or big companies have probability of being in a financial crisis (Liang et al., 2015).

\section{Log of Total Assets}

\section{Research Hypotesis}

The effect of profitability on financial distress. When the company's sales level increases, the level of income also increases, this has an impact on the company's profitability which is higher than before. Increased corporate profits mean that the company's profitability ratio is in a positive point. Positive profitability indicates that the company's financial condition is in a stable condition so that investors will be more interested in investing in the company, so that the possibility of the company being in a condition of financial distress is less likely. Research conducted by Khaliq et al. (2014), Restianti and Agustina (2018) said that profitability ratios have a significant effect on financial distress, so it can be said that the greater the profitability ratios, the company is in a good financial condition and avoiding financial distress, so that the proposed hypothesis is as follows:

$\mathrm{H}_{1}$ : Profitability has a negative effect on financial distress.

Effect of Liquidity on Financial Distress. Liquidity ratios indicate the ability of a company to pay off short-term liabilities that are due or that must be fulfilled immediately. To fulfill company obligations, the amount of assets available to pay off company obligations must be higher than the liabilities that are due. If a company finds it difficult to pay off their short-term obligations, the company will be vulnerable to financial crisis. Habib et al., (2013)states that liquidity ratios have a negative and significant effect on financial distress, so it can be said that the opportunity for a company to experience financial distress will be 


\section{Theresia Trisanti}

smaller when the company has sufficient funds to pay off obligations that have matured so that there is no outstanding debt to be paid. But research conducted by Lian, (2017) found different results, namely liquidity had no significant effect on financial distress. Based on the statement above, the hypothesis made is:

$\mathrm{H}_{2}$ : Liquidity has a negative effect on financial distress.

Effect of Leverage on Financial Distress. One way the company gets an injection of funds is by debt, but debt can make the company have to pay the entire amount of debt plus interest determined by the lender. When companies use more debt as capital this causes the company's leverage ratio to be high. The leverage ratio will measure how much the company's assets are financed with debt. Companies that finance more use debt, it is feared that the company will experience difficulties when the payment due is smaller than the debt owned by the company. If this happens the potential for the company to experience financial distress will be higher and when it continues does not rule out the company will go bankrupt. Research conducted by Restianti and Agustina (2018) shows that leverage ratios have a positive and significant effect on financial distress, so it can be concluded that the greater the company uses debt as an injection of funds, the greater the potential for companies to experience financial distress. Thus the hypothesis formulated is:

\section{$\mathrm{H}_{3}$ : Leverage has a positive effect on financial distress}

Effect of Sales Growth on Financial Distress. Sales growth is an indicator of a company's demand and competitiveness in an industry. According to Mselmi et al., (2017) also states that sales growth is an increase in the number of sales from year to year or from time to time. High sales growth, it will reflect the company's revenue which also increases. The rate of growth of a company will affect the ability to maintain profits in marking future opportunities. The increase in sales growth reflects that the company implemented a good marketing strategy so that the company's sales experienced an increase which then led to an increase in the company's sales. If the company's revenue increases, the company's profit also increases. Thus the possibility of companies experiencing financial distress is smaller, so that the proposed hypothesis is as follows:

$\mathrm{H}_{4}$ : Sales Growth has a negative effect on financial distress.

The financial characteristics of the company can be seen from the size of the company. Company size is a scale that can be calculated by the level of total assets and sales which can indicate the condition of the company where a larger company will have an excess in the source of funds obtained to finance its investment in obtaining a profit. Large companies that are well established will find it easier to obtain capital in the capital market compared to small companies. Large companies that are already established or have a strong position can easily get more fund of money, meaning that the flexibility a large company has is greater than that of a small company ( $\mathrm{Li} \& \mathrm{Du}, 2011)$. Because this ease of access means that large companies have greater flexibility, it is assumed that large companies are more resilient in facing financial distress than smaller companies. Thus for the four mediating hypothesis formulated as follows: 


\section{Theresia Trisanti}

$\mathrm{H}_{5}$ : Company size mediating the relationship between profitability and financial distress.

$\mathrm{H}_{6}$ : Company size mediating the relationship between liquidity and financial distress.

$\mathrm{H}_{7}$ : Company size mediating the relationship between leverage and financial distress.

$\mathrm{H}_{8}$ : Company size mediating the relationship between sales growth and financial distress.

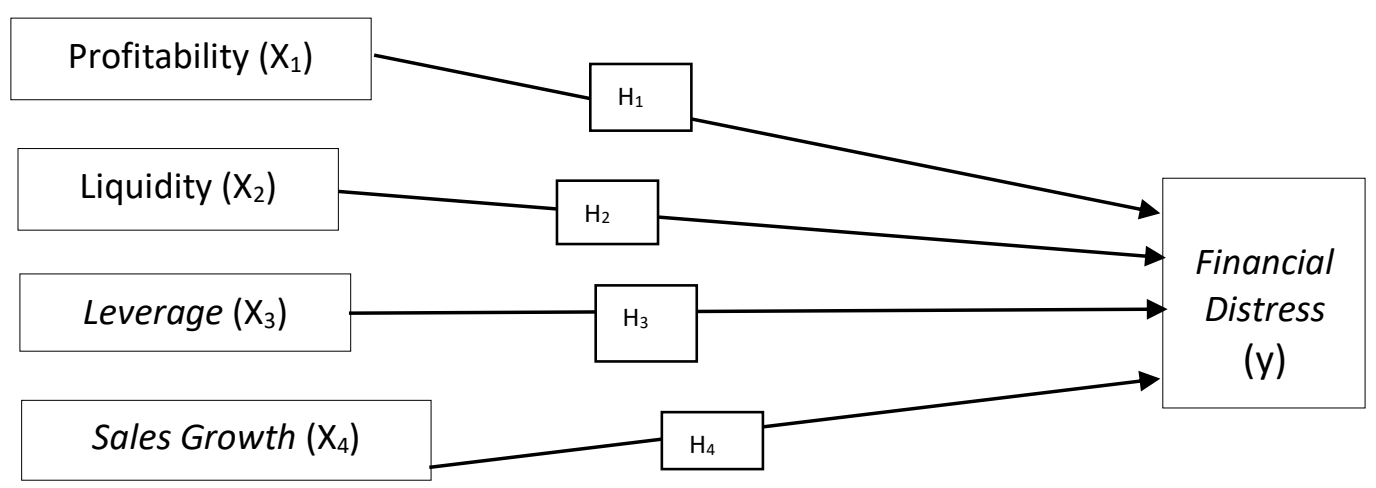

Figure 1. Research Framework

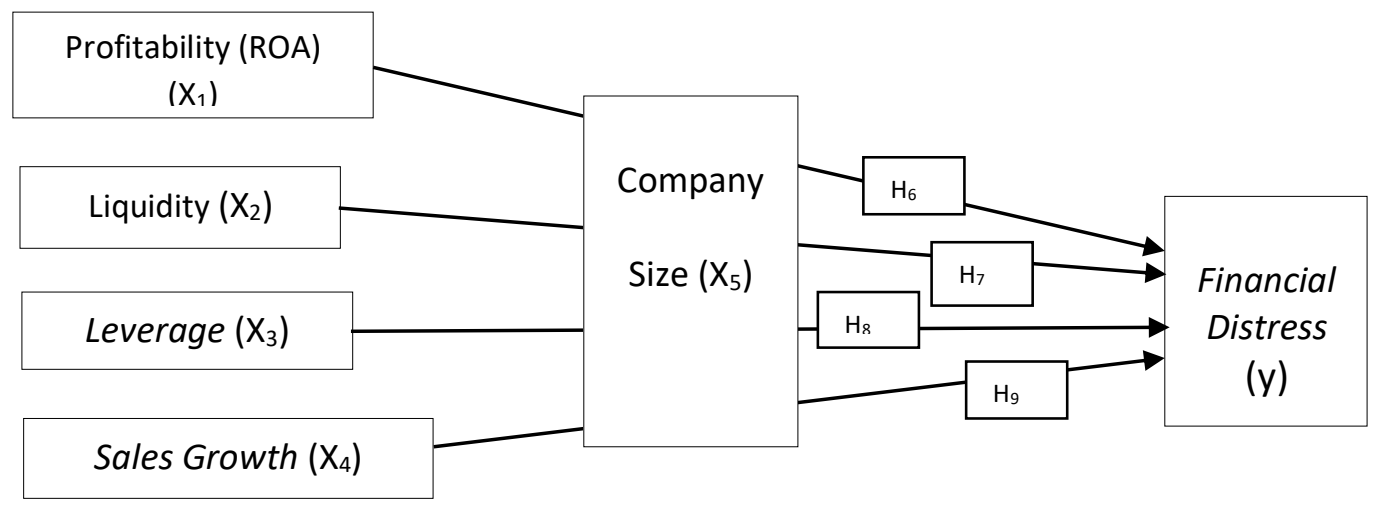

Figure 2. Research Framework

\section{Research Finding and Discussions}

In this study, the data used are secondary data obtained from the annual report of each sample company. In the annual report, the researcher looks for and collects data related to operational variables in the study. The object of research or population used in this study are property and real estate companies listed on the Indonesia Stock Exchange (BEI) in 2016 2019.The data collected as many as 41 samples property and real estate companies selected to be the research sample with a research period of 4 years, namely starting 2016 to 2019 . Sampling criteria have been determined before, so companies were selected which were ultimately used as research samples. The research sample selection is detailed as follows: 


\section{Theresia Trisanti}

Table 1 Sample criteria

\begin{tabular}{clc}
\hline No. & \multicolumn{1}{c}{ Criteria } & Amount \\
\hline 1 & $\begin{array}{l}\text { Property and Real Estate Companies listed on the IDX } \\
\text { The company reports financial statement data continuously in }\end{array}$ & 56 \\
& $\begin{array}{l}\text { the 2016-2019 period } \\
2\end{array}$ & $\begin{array}{l}\text { Information related to the variables in the study available by } \\
\text { the company }\end{array}$ \\
3 & 4 Years of observation (41 X 4) & 164 \\
\hline
\end{tabular}

R Square shows the ability of student behavior engagement, student cognitive engagement and student emotional engagement in this research model to explain variations in online learning satisfaction, which is 0.646 . The value of $R$ Square $\left(R^{2}\right)=0.671$ greater than 0.50 is classified as all independent variables have ability to explain variations in the dependent variable.

Table 2. List of R Square

\begin{tabular}{lrr}
\hline Variable & R Square & R Square Adjusted \\
\hline Company Size & 0,462 & 0,442 \\
Financial Distress & 0,671 & 0,646 \\
\hline
\end{tabular}

The following are the results of the PLS Algorithm processing in the research model used are as follows:

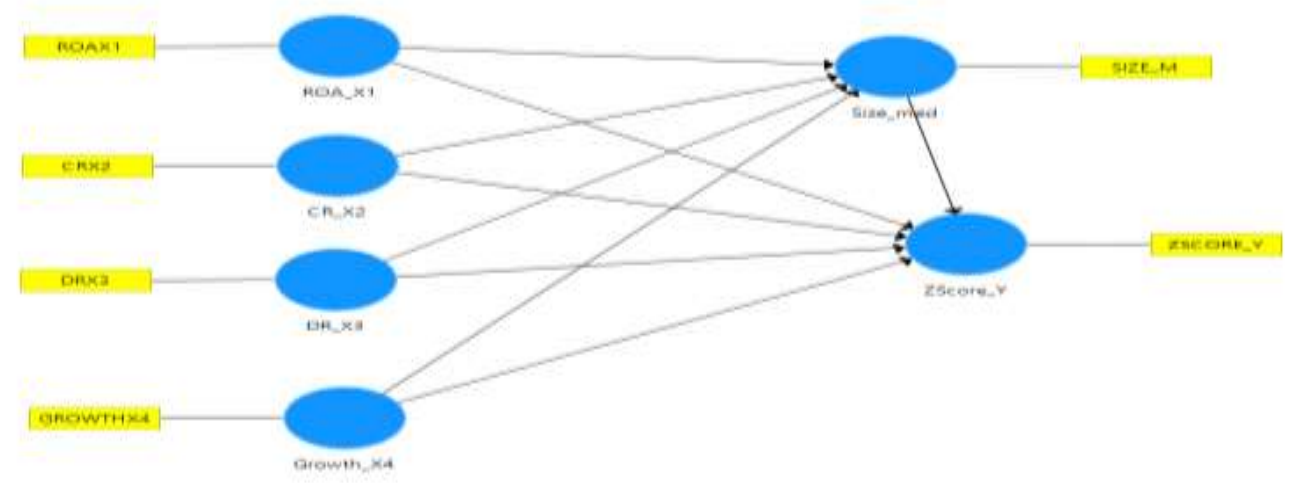

Table 3. Hypothesis Result

\begin{tabular}{|l|r|r|r|r|r|}
\hline \multicolumn{1}{|c|}{ Path Coefficients } & Hypothesis & $\begin{array}{c}(\beta) \\
\text { Original } \\
\text { sample }\end{array}$ & \multicolumn{1}{c|}{$\begin{array}{c}\text { Sample } \\
\text { Mean }\end{array}$} & $\begin{array}{c}\text { T } \\
\text { Statistics }\end{array}$ & P Value \\
\hline Profitability $\left(\mathrm{X}_{1}\right) \rightarrow$ ZScore_Y & $\mathrm{H}_{1}$ & $-0,364$ & 0,367 & 5,097 & 0,013 \\
\hline Liquidity $\left(\mathrm{X}_{2}\right) \rightarrow Z$ ZScore_Y & $\mathrm{H}_{2}$ & $-0,628$ & 0,650 & 8,358 & 0,002 \\
\hline Leverage $\left(\mathrm{X}_{3}\right) \rightarrow$ ZScore_Y & $\mathrm{H}_{3}$ & 0,484 & 0,483 & 6,733 & 0,000 \\
\hline $\begin{array}{l}\text { Growth Sales } \\
\left(\mathrm{X}_{4}\right) \rightarrow \text { ZScore_Y }\end{array}$ & $\mathrm{H}_{4}$ & $-0,004$ & $-0,006$ & 0,676 & 0,208 \\
\hline Size(Med) $\rightarrow$ ZScore_Y & $\mathrm{H}_{5}$ & $-0,166$ & $-0,163$ & 3,050 & 0,038 \\
\hline
\end{tabular}


Table 4. Specific Indirect Hypotheses Result Effect

\begin{tabular}{|c|c|c|c|c|c|c|}
\hline H & $\begin{array}{l}\text { Influence } \\
\text { Between } \\
\text { Pathways }\end{array}$ & $\begin{array}{c}\text { Beta } \\
\text { (Origina } \\
1 \\
\text { Sample) }\end{array}$ & $\begin{array}{l}\text { Samp } \\
\text { le } \\
\text { Mean }\end{array}$ & $\begin{array}{c}\text { T- } \\
\text { Statisti } \\
\text { c }\end{array}$ & $\begin{array}{c}\text { P- } \\
\text { value }\end{array}$ & Meaning \\
\hline $\mathrm{H}_{6}$ & $\begin{array}{l}\text { Profitability }\left(\mathrm{X}_{1}\right) \\
\rightarrow \text { Size } \\
\rightarrow \text { ZScore_Y }\end{array}$ & $-0,364$ & 0,367 & 5,097 & 0,003 & $\begin{array}{l}\text { Profitability has effect on } \\
\text { financial distress with } \\
\text { Company size as an } \\
\text { intervening variable. }\end{array}$ \\
\hline $\mathrm{H}_{7}$ & $\begin{array}{l}\text { Liquidity }\left(\mathrm{X}_{2}\right) \rightarrow \\
\text { Size } \rightarrow \text { ZScore_Y }\end{array}$ & $-0,018$ & 0,178 & 2,131 & 0,001 & $\begin{array}{l}\text { Liquidity has effect on } \\
\text { financial distress with } \\
\text { Company size as an } \\
\text { intervening variable. }\end{array}$ \\
\hline $\mathrm{H}_{8}$ & $\begin{array}{l}\text { Leverage }\left(\mathrm{X}_{2}\right) \rightarrow \\
\text { Size } \rightarrow \mathrm{ZScore} \text { YY }\end{array}$ & 0,423 & 0,401 & 4,639 & 0,002 & $\begin{array}{l}\text { Leverage has effect on } \\
\text { financial distress with } \\
\text { Company size as an } \\
\text { intervening variable. }\end{array}$ \\
\hline $\mathrm{H}_{9}$ & $\begin{array}{l}\text { Growth Sales } \\
\left(\mathrm{X}_{2}\right) \rightarrow \text { Size } \\
\rightarrow \text { ZScore_Y }\end{array}$ & $-0,004$ & $-0,016$ & 0,676 & 0,208 & $\begin{array}{l}\text { Growth has no effect on } \\
\text { financial distress with } \\
\text { Company size as an } \\
\text { intervening variable. }\end{array}$ \\
\hline
\end{tabular}

Based on the hypothesis results Table 3 above, research and discussion on the effect of profitability, liquidity, company size, leverage and sales growth on financial distress both simultaneously and partially with the following conclusions can be drawn as follows: the first hypothesis, which tests the relationship between profitability and financial distress, shows that original sample $(\beta)$ value is $-0,364$ and the t-statistic is 5,097. The measurement results show that the P-value 0,003, so the first hypothesis in this study is accepted. From the results of these data, it can be interpreted that the sample data of the independent (eksogen) variable (profitability) has significant relationship with financial distress as the dependent (endogen) variable. For the second hypothesis, which tests the relationship between liquidity and financial distress, shows that the original sample value $(\beta)$ is $-0,628$ and the t-statistic is 8,358 . The measurement results show that the P-value 0,038 , so the second hypothesis in this study is accepted. From the results of these data, it can be interpreted that the sample data of the independent variable liquidity has succeeded in proving the relationship with financial distress as the dependent (endogen) financial distress.

For the third hypothesis, which tests the relationship between leverage and financial distress, shows that the $(\beta)$ original sample value is 0,484 and the statistic is 6,733 . The measurement results show that the P-value 0,000 so the third hypothesis in this study is accepted. The leverage variable has an effect on financial distress but has positive relationship with the existing hypothesis, so that the higher the level of corporate leverage causes the level of the company to experience financial distress is higher. This is because the company has the payment of loan to the debtor also affects the company entered in to financial distress condition. For the fourth hypothesis, which tests the relationship between sales growth and financial distress, shows that the $(\beta)$ original sample value is $-0,004$ and the 


\section{Theresia Trisanti}

statistic is 0,676 . The measurement results show that the $\mathrm{P}$-value 0,208 , independent (eksogen) variable (growth) no significant relationship with financial distress as the dependent (endogen) variable. The sales growth variable is not significant to financial distress because the company gets an injection of funds in the form of issuance of stocks and bonds from investors or loan funds from creditors, so that even though the company's sales growth rate is negative, the company can still support the company's operational activities.

According to Hair Jr. et al (2014) there are 2 (two) types of mediation, namely partial mediation and perfect mediation. Partial mediation occurs when the direct effect (independent variable $=>$ dependent variable) is significant and the indirect effect (independent variable $\Rightarrow$ mediation $=>$ dependent variable) is also significant. Meanwhile, perfect mediation occurs when the direct effect (independent variable $\Rightarrow$ dependent variable) is not significant and the indirect effect (independent variable $\Rightarrow$ mediation $\Rightarrow$ dependent variable) is significant. Based on table 4 it can be seen for $\mathrm{H}_{6}$ up to $\mathrm{H}_{8}$ firm size can act as partial mediating variable for profitability, liquidity and leverage. For the hypotheses9, firm size can't act as mediating variable has a negative signed path regression with coefficient $(\beta)-0.187$ and with a significance level of 0,208 which is bigger than 0.05 .

\section{Conclusion, Limitation and Suggestions}

From the results of research and discussion above the following conclusions can be drawn as follows: profitability, liquidity and company size affects financial distress in Property and Real Estate companies. Size can mediating the relationship of profitability, liquidity, company size and leverage, but not mediating sales growth variable.

This study had limitation as follows: research only uses Property and Real Estate populations listed on the IDX, therefore this causes the results of research can't be generalized to all types of companies. Researcher have not examined other variables such as activity ratios, cash flow and management tenure so on.

Based on the results of research and discussion, the suggestions for future research as follows:

1. For investors, Investors need to pay attention to whether the company is in financial distress or not before making or deciding to invest.

2. For companies the management needs to consider the factors that influence the condition of financial distress further so that the company can avoid bankruptcy.

3. For further researchers, future studies can add other variables that might affect financial distress and can use other methods in determining financial distress conditions in companies such as using the CAMEL, Springate's method and other variables such as management structure, audit committee, activity ratios.

\section{References}

Almilia, L. S., \& Kristijadi, E. (2003). Analisis Rasio Keuangan Untuk Memprediksi Kondisi Financial Distress Perusahaan Manufaktur Yang Terdaftar di Bursa Efek Jakarta. Jurnal Akuntansi \& Auditing Indonesia.

Andre, O., \& Taqwa, S. (2014). Pengaruh Profitabilitas, Likuiditas , dan Leverage Dalam Memprediksi Financial Distress (Studi Empiris Pada Perusahaan Aneka Industri yang Terdaftar di BEI Tahun 2006-2010). Jurnal WRA.

Betz, F., Oprică, S., Peltonen, T. A., \& Sarlin, P. (2014). Predicting distress in European 
banks. Journal of Banking and Finance. https://doi.org/10.1016/j.jbankfin.2013.11.041

Bhattacharjee, A., \& Han, J. (2014). Financial distress of Chinese firms: Microeconomic, macroeconomic and institutional influences. China Economic Review. https://doi.org/10.1016/j.chieco.2014.07.007

Chen, Yehning, Weston, J. F., \& Altman, E. I. (1995). Financial Distress and Restructuring Models. Financial Management. https://doi.org/10.2307/3665535

Chen, Yibing, Zhang, L., \& Zhang, L. (2013). Financial distress prediction for chinese listed manufacturing companies. Procedia Computer Science. https://doi.org/10.1016/j.procs.2013.05.088

Couwenberg, O. (2015). Financial Distress. In Wiley Encyclopedia of Management. https://doi.org/10.1002/9781118785317.weom040039

Elfakhani, S., \& Lung, T. (2003). The effect of split announcements on Canadian stocks. Global Finance Journal, 14(2), 197-216. https://doi.org/10.1016/S10440283(03)00012-7

Elkamhi, R., Ericsson, J., \& Parsons, C. A. (2012). The cost and timing of financial distress. Journal of Financial Economics. https://doi.org/10.1016/j.jfineco.2012.02.005

Fitzpatrick, J., \& Ogden, J. P. (2011). The detection and dynamics of financial distress. International Review of Finance. https://doi.org/10.1111/j.1468-2443.2010.01119.x

Garcia-Appendini, E. (2018). Financial distress and competitors' investment. Journal of Corporate Finance. https://doi.org/10.1016/j.jcorpfin.2018.06.003

Gopalan, R., \& Xie, K. (2011). Conglomerates and industry distress. Review of Financial Studies. https://doi.org/10.1093/rfs/hhr060

Habib, A., Uddin Bhuiyan, B., \& Islam, A. (2013). Financial distress, earnings management and market pricing of accruals during the global financial crisis. Managerial Finance. https://doi.org/10.1108/03074351311294007

Husein, M. F., \& Pambekti, G. T. (2015). Precision of the models of Altman, Springate, Zmijewski, and Grover for predicting the financial distress. Journal of Economics, Business \& Accountancy Ventura. https://doi.org/10.14414/jebav.v17i3.362

Keasey, K., Pindado, J., \& Rodrigues, L. (2015). The determinants of the costs of financial distress in SMEs. International Small Business Journal: Researching Entrepreneurship. https://doi.org/10.1177/0266242614529317

Khaliq, A., Motawe Altarturi, B. H., Mohd Thas Thaker, H., Harun, M. Y., \& Nahar, N. (2014). Identifying Financial Distress Firms: A Case Study of Malaysia', s Government Linked Companies ( GLC ). International Journal of Economic, Finance and Management.

Korteweg, A. G. (2011). The Costs of Financial Distress Across Industries. SSRN Electronic Journal. https://doi.org/10.2139/ssrn.945425

Kristanti, F. T., Rahayu, S., \& Huda, A. N. (2016). The Determinant of Financial Distress on Indonesian Family Firm. Procedia - Social and Behavioral Sciences. https://doi.org/10.1016/j.sbspro.2016.05.018

Li, J., \& Du, W. (2011). An empirical study on the corporate financial distress prediction based on logistic model: Evidence from China's manufacturing Industry. International Journal of Digital Content Technology and Its Applications. https://doi.org/10.4156/jdcta.vol5.issue6.44

Lian, Y. (2017). Financial distress and customer-supplier relationships. Journal of Corporate Finance. https://doi.org/10.1016/j.jcorpfin.2017.02.006

Liang, D., Tsai, C. F., \& Wu, H. T. (2015). The effect of feature selection on financial 
INOBIS: Jurnal Inovasi Bisnis dan Manajemen Indonesia

Volume 03, Nomor 03, Juni 2020

Theresia Trisanti

distress prediction.

https://doi.org/10.1016/j.knosys.2014.10.010

Knowledge-Based Systems.

Louwers, T. J. (1998). The Relation between Going-Concern Opinions and the Auditor's Loss Function. Journal of Accounting Research. https://doi.org/10.2307/2491325

Md-Rus, R., Mohd, K. N. T., Latif, R. A., \& Alassan, Z. N. (2013). Ownership Structure and Financial Distress. Journal of Advanced Management Science. https://doi.org/10.12720/joams.1.4.363-367

Miglani, S., Ahmed, K., \& Henry, D. (2015). Voluntary corporate governance structure and financial distress: Evidence from Australia. Journal of Contemporary Accounting and Economics. https://doi.org/10.1016/j.jcae.2014.12.005

Mselmi, N., Lahiani, A., \& Hamza, T. (2017). Financial distress prediction: The case of French small and medium-sized firms. International Review of Financial Analysis. https://doi.org/10.1016/j.irfa.2017.02.004

Oaten, M., \& Cheng, K. (2007). Improvements in self-control from financial monitoring. Journal of Economic Psychology. https://doi.org/10.1016/j.joep.2006.11.003

Phillips, G., \& Sertsios, G. (2013). How do firm financial conditions affect product quality and pricing? Management Science. https://doi.org/10.1287/mnsc.1120.1693

Platt, H. D. (1995). Teaching Turnaround Management and Bankruptcy. Financial Practice and Education.

Platt, H. D., Platt, M. B., \& Chen, G. (1995). Sustainable growth rate of firms in financial distress. Journal of Economics and Finance. https://doi.org/10.1007/BF02920515

Platt, H., \& Platt, M. (2008). Financial Distress Comparison Across Three Global Regions. Journal of Risk and Financial Management. https://doi.org/10.3390/jrfm1010129

Restianti, T., \& Agustina, L. (2018). The Effect of Financial Ratios on Financial Distress Conditions in Sub Industrial Sector Company. Accounting Analysis Journal. https://doi.org/10.15294/aaj.v5i3.18996

Rohmadini, A., Saifi, M., \& Darmawan, A. (2018). Pengaruh Profitabilitas, Likuiditas dan Leverage Terhadap Financial Distress (Studi Pada Perusahaan Food \& Beverage Yang Terdaftar Di Bursa Efek Indonesia Periode 2013-2016). Jurnal Administrasi Bisnis.

Senbet, L. W., \& Wang, T. Y. (2010). Corporate financial distress and bankruptcy: A survey. In Foundations and Trends in Finance. https://doi.org/10.1561/0500000009

Shahwan, T. M. (2015). The effects of corporate governance on financial performance and financial distress: evidence from Egypt. Corporate Governance (Bingley). https://doi.org/10.1108/CG-11-2014-0140

Xu, Y., Beller, A. H., Roberts, B. W., \& Brown, J. R. (2015). Personality and young adult financial distress. Journal of Economic Psychology. https://doi.org/10.1016/j.joep.2015.08.010

Yudiawati, R., \& Indriani, A. (2016). Analisis Pengaruh Current Ratio, Debt To Total Asset Ratio, Total Asset Turnover, dan Sales Growth Ratio Terhadap Kondisi Financial Distress Pada Perusahaan Manufaktur. DIPONEGORO JOURNAL OF MANAGEMENT. 